of the U.S. National Academy of Sciences of the United States, a Foreign Member of the Academy of Sciences of the U.S.S.R., an Honorary Member of the Polish Chemical Society and the Belgian Chemical Society, and an Honorary Fellow of the Chemical Society of London.

Among other honours, Dr. Steacie was awarded the Gold Medal of the Professional Institute of the Public Service of Canada (1949), the Palladium Medal of the Chemical Institute of Canada (1953), the Tory Medal of the Royal Society of Canada (1955), and eighteen honorary degrees.

One of Dr. Steacie's principal interests was the development of Canada's universities. He was at the time of his death serving as chairman of the Board of Governors of Carleton University, and chairman of the Advisory Committee for Science of the University of Ottawa.

Dr. Steacie's scientific work was in the fields of photochemistry, the kinetics of gas reactions, and free radical reactions, important as the basis of petroleum technology. The work consisted of fundamental research, without immediate application, but making outstanding contributions to basic knowledge. He had published more than two hundred scientific papers, and was the author of three books. One of his books, Atomic and Free Radical Reactions, is regarded as the standard text on that subject.

Besides serving as president of the National Research Council, Dr. Steacie was a member of the Defence Research Board and the Atomic Energy Control Board, and a director of Canadian Patents and Development Limited and the Canadian Standards Association.

\section{Dr. J. W. T. Walsh, O.B.E.}

By the death of Dr. J. W. T. Walsh on July 17 , at the age of seventy, the world has lost one of its leading figures in the field of lighting and photometry. Dr. Walsh was a man of very wide interests and had long been held, both nationally and internationally, in the highest regard and esteem.

Educated at Hampton Grammar School and Merton College, Oxford, he went to the National Physical Laboratory to work under Sir Clifford Paterson (then Mr. C. C. Paterson), and when the latter left the Laboratory in 1919 , Dr. Walsh remained to take charge of the work on photometry, until his retirement in 1951. During this period, he was able to exercise, through his position at the Laboratory, a considerable influence on the advances made in photometry, particularly those concerned with the change from visual to physical methods of measurement and with the adoption internationally of a black body radiator as the primary standard of light in place of sets of filament lamps.

His versatile gifts were used to the full on many other aspects of his subject. He served on numerous committees, a specially important one being the Home Office Committee which drew up the first regulations for standards of lighting in factories. $\mathrm{He}$ became a founder member of the British Standards Institution Illumination Industry Standards Committee in 1927 and served as its chairman during 1945-55; the subjects in which he was particularly interested were street lighting and nomenclature. He also wrote a number of books, notably his text. book on Photometry, the latest of three editions having been published in 1958. In addition, he was the author of numerous papers.
In 1929 he was elected to membership of the Institution of Electrical Engineers, after being an associate member from 1918, and was awarded the Kelvin and Ayrton premiums.

For many years he played a very active part in the Illuminating Engineering Society and he achieved the unique distinetion of being elected its president on two separate occasions, in 1929 and 1947.

Dr. Walsh's interest in illumination extended also to the work of the National Illumination Committee, to which he was appointed as the representative of the National Physical Laboratory as far back as 1919. He served as chairman during 194555. This work brought him into close touch with the parent International Commission on Illumination, the general secretary of which was provided by the National Physical Laboratory for the period between the ends of the two World Wars. Dr. Walsh himself was the first to hold office in this period (during 1921-28) and was honorary secretary during 1928-31. He attended every meeting of the Commission up to the most recent one in 1959. Throughout this time he steadily built up a reputation as one of the Commission's leading figures and in 1948 was appointed one of its vice-presidents. Later, in 1955, full recognition was given to him by his appointment as president and he duly presided over the next meeting at Brussels in 1959. It is understood that he had recently completed a history of the Commission, and the publication of this will be awaited with much interest.

Recognition of his work was acknowledged in 1951 by his appointment as an Officer of the Order of the British Empire.

During his early time at the National Physical Laboratory Dr. Walsh took a considerable interest in its social activities, but later much of his private life was devoted to youth work, both on behalf of organizations such as the Boy Scouts and in numerous individual cases. He was also interested in education and served on a number of local bodies. He gave a start in life to very many less fortunate than himself.

Although a bachelor with few family connexions, he was by his wide and humane interests a man with innumerable friends in many countries and his passing will be universally mourned.

\section{J. S. Preston \\ L. H. MoDermotT}

\section{Prof. S. Mangham}

Sydney Mangham, who died on July 30 at the age of 76, was the first professor of botany in what was then the University College of Southampton. Sutherland, and before him Cavers, had been professors of biology; but in 1920 the department was divided. Sherriffs was made head of the department of zoology, and Mangham was appointed to the new chair of botany. For the first seven years of his professorship Mangham's staff consisted of one lecturer, Miss F. M. Loader (who remained with him during the whole of his tenure), a temporary and ever-changing student assistant, and a lab-boy; and Mangham taught virtually all branches of botany at all levels, including a course for gardeners. Had he been a man of strong research interests, the task would have been intolerable; but his early interests in analytical techniques and in translocation rapidly succumbed to his genuine love of teaching. Dissatisfied with existing introductory text-books he wrote A First Biology and A Second Biology with 
Sherriffs; then A Text-Book of Biology with Hockley; and, lastly, the still-popular Earth's Green Mantlethe title of which was borrowed by Tansley, with Mangham's permission, for his own Britain's Green Mantle. Mangham was a first-class draughtsman, and his elegant diagrams contributed much to the success of his books.

$\mathrm{He}_{e}$ enjoyed field excursions, and at 65 could still out-walk many of his students; he knew his plants and was not alone in finding nomenclatural changes exasperating; and he loved - and was justly proud of - his garden. After his retirement in 1951, and after an Australian tour, he returned to the now University of Southampton as curator of grounds, a post which gave him great pleasure and which he filled with distinction until, on the death of his wife in 1957, he moved from the town.

Few of us to-day would be willing to do as much as Mangham did with so little assistance, and to devote thirty years to keoping a small Department going at the cost of our own scientific work and advancement. But his faith in the importance of his subject and in the future of his Department was proof against all inadequacies of staff, finance and space, and he laboured selflessly to ease the path of his successor. The building which he and an engineering colleague personally designed-without the help of an architect -is still in use to-day; and his memory is honoured in the Department, the continued existence of which he made possible.

\section{W. T. WILLIAMs}

\section{NEWS and VIEWS}

Botany at Glasgow : Prof. J. Walton

Prof. JoHn Walton, regius professor of botany in the University of Glasgow since 1930, who retired on September 30, was educated at Daniel Stewart's College, Edinburgh, and St. John's College, Cambridge (where he was awarded the Hutchinson Research Studentship). He went as botanist on the First Oxford Expedition to Spitsbergen in 1921 and on his return to Cambridge was appointed junior demonstrator. His palæobotanical researches were there begun under the late Sir Albert Seward. From 1923 he held the post of lecturer in botany in the University of Manchester until his appointment to the Glasgow chair. Part of his early work was concerned with now techniques of investigating fossil plants. In 1923 he published an account of his balsam transfer method, whereby plant compressions could be transferred to a transparent base to facilitate microscopic examination. His well-known 'peel' technique, a rapid and easy method of obtaining thin sections of petrified fossil plants, was published in 1928. Another of his early publications was concerned with the factors affecting the form of fossil plants. Most of his work, however, consisted of investigations of Palæozoic plants, particularly those of the Welsh and Scottish Lower Carboniferous. Over the years our knowledge of these strata, which are of special importance in fossil botany, has been greatly increased by Walton and his students. However, the foregoing are only indications, for his interests in both fossil and living plants extended over a wide field.

Among his many distinctions, Walton was awarded the degrees of D.Sc. (Manchester), Sc.D. (Cantab.) and the honorary degrees of Ll.D. of McMaster University and D.-ès.-Sc. of the University of Montpellier. In 1931 he was elected a Fellow of the Royal Society of Edinburgh, on the Council of which he served for some years. During $1949-53$ he was a Forestry Commissioner and during the same period he served as a member of the Scottish Committee of the Nature Conservancy. He was elected president of the Botanical Society of Edinburgh, 1962. Among his many other social and scholarly interests and activitios, it was perhaps no less than appropriate that he, the son of a distinguished artist, should have served as honorary curator of the very important art collections belonging to the University of Glasgow.
Dr. P. W. Brian, F.R.S.

Dr. Perdy Wragg Brian, who succeeds Prof. Walton in the regius chair of botany at Glasgow, has for the past twenty-six years been on the scientific staff of Imperial Chemical Industries, Ltd., from 1936 until 1946 as mycologist at the Jealott's Hill Research Station, Bracknell, Berks., since then as head of the Department of Microbiology, Akers Research Laboratories, Welwyn, Herts. Dr. Brian was educated at King Edward's School, Birminghan, and at King's College, Cambridge. He held the Frank Smart studentship in botany at Cambridge in 1933-34 and spent the next two years as assistant plant pathologist at the Long Ashton Research Station. Dr. Brian's versatility is well known. His personal research work has included notable contributions to both agriculture and industrial microbiology, while he has inspired a team of mycologists, microbiologists and chemists to break much new ground in the field of biologically active substances produced by fungi. Among the numerous antibiotics first characterized by Dr. Brian, mention may be made of griseofulvin, which in addition to its horticultural use as a systemic fungicide has during the past fow years become notorious for its use in the oral therapy of ringworm of man and animals. Another notable series of his researches has been concerned with the gibberellins. Dr. Brian gave the Cantor lectures to the Royal Society of Arts in 1953 , was elected to the Royal Society in 1958, served the British Mycological Society as president in 1960, and in 1961-62 was similarly honoured by the Association of Applied Biologists. He will bring this wide experience of applied microbiology to the University of Glasgow when next year he takes up his new post.

\section{National Coal Board Research and Development Organization}

WrrH effect from October 1, the National Coal Board made changes in the departmental responsibilities for research and development. That directly concerned with the production, working and proparation of coal became the responsibility of the production member of the Board, Mr. H. E. Collins, and that concerned with coal processing and combustion became the responsibility of the scientific member of the Board, Mr. A. H. A. Wynn. The main effect of these changes is that the Mining Research Estab- 